\title{
Lesões crônicas de tendões flexores na mão - Reconstrução em dois estágios
}

\author{
Chronic flexor tendon lesions \\ - Reconstruction in two stages
}

\begin{abstract}
Samuel Ribak', Marcelo Rosa de Resende², Robinson Dalapria ${ }^{3}$, Edison Hirata ${ }^{3}$, Márcia Muquy', Renato Pinheiro Cordeiro ${ }^{4}$, Dirceu de Andrade ${ }^{5}$, Celso Silva Toledo ${ }^{5}$
\end{abstract}

\section{RESUMO}

Os autores apresentam resultados de tratamento de lesões crônicas dos tendões flexores na mão, usando técnica em dois estágios. O primeiro pelo implante de prótese de silicone e o segundo com enxerto de tendão. Dão detalhes de técnica, e analisam seus resultados comparando-os com os da literatura. Chegam a conclusão que a técnica dá resultados satisfatórios na maioria dos casos.

Descritores: Tendões flexores, lesões crônicas, enxertos de tendão.

\section{INTRODUÇÃO}

O tratamento das lesões crônicas dos tendões flexores da mão, ainda hoje, é um desafio pela grande freqüência de aderência do tendão usado como enxerto.

O conceito atual de tratamento deste tipo de lesão é a reconstrução em dois estágios. O primeiro, onde se coloca um material sintético no trajeto do tendão objetivando a formação de um neotúnel que possa receber o enxerto biológico que será utilizado em um segundo tempo da reconstrução.

A utilização de implantes iniciou-se em $1936^{(13)}$, em clássica experiência com tubos de celulóides, na qual observou-se a formação de uma pseudobainha, composta por células adaptadas em aceitar uma estrutura de deslizamento, no caso a estrutura de tendão. Esta técnica não obteve o sucesso esperado, pois sendo o material muito rígido, impedia a mobilização passiva das articulações, resultando em rigidez do dedo. Somente em 1963(2) é que se iniciou a utilização de espaçadores mais flexíveis, de material tipo silicone

Outras propostas de tratamento em dois estágios incluíam a utilização de enxerto de tendão, como o vascularizado, do flexor superficial do mesmo dedo, conforme trabalho em1969 ${ }^{(14)}$, que apesar de bastante interessante, desconsiderava a utilização do

\section{SUMMARY}

The authors present the results of a two-stage treatment of chronic flexor tendon injuries of the hand. In the first stage a silicone prosthesis is implanted and in the second stage a tendon graft. Details of the technique and results of the analysis are presented and compared with the scientific literature. The authors concluded that satisfactory results were achieved in most of the cases.

Key Words: Flexor tendon, chronic injuries, tendinous grafting.

\section{INTRODUCTION}

The treatment of chronic lesions in the hand flexor tendons is challenging due to the high frequency of adherence of the tendon used as graft.

The current concept of treatment for that kind of lesion is reconstruction in two stages. In the first, a synthetic material is placed in the trajectory of the tendon to form a tunnel which can receive the biological graft to be used in the second stage of reconstruction.

The utilization of implants was introduced ${ }^{(13)}$ in 1936, in a classic experience with celluloid tubes, where a pseudoshaft was formed, composed by cells adapted to accept a sliding structure, in that case the tendon structure. That technique failed since the material was too rigid and prevented the passive mobilization of the articulations resulting in rigidity of the finger. Only in $1963^{(2)}$ the utilization of rods made of a more flexible silicone type material was instituted.

Other proposals of two-stage treatment(14) study (1969), mentioned the utilization of tendon grafts, as the vascularized superficial flexor of the same finger that, in spite of being very interesting, did not consider the utilization of the implant
Trabalho realizado no Hospital Nossa Senhora do Pari - São Paulo - SP

1- Médico Preceptor. Mestre em Ortopedia pela FMUSP

2- Médico Assistente da IOT - Hospital das Clínicas, FMUSP

3- Médico Ortopedista

4- Residentes do Hospital Nossa Senhora do Pari

5- Diretor do Hospital Nossa Senhora do Pari

Endereço para correspondência: Rua das Hortências, 451 - Granja Viana Carapicuiba - SP - CEP 06355-370 - Email: samuelribak@aol.com

Trabalho recebido em 08/10/2001. Aprovado em 28/03/2002
*Work performed at the Hospital Nossa Senhora do Pari - São Paulo - SP

1- Preceptor. Master Degreein Orthopedics, FMUSP 2- IOT Assistant Doctor - "Hospital das Clínicas", FMUSP 3- Orthopedic Surgeon

4- Residents of the Hospital Nossa Senhora do Pari

5- Directors of Hospital Nossa Senhora do Pari

Address: Rua das Hortências, 451 - Granja Viana - Carapicuiba - SP CEP 06355-370 - Email: samuelribak@aol.com 
implante no primeiro tempo. Somente em 1971 foi que aprimoraram e detalharam a técnica de reconstrução tendínea em 2 estágios da forma como hoje conhecemos, incluindo relatos clínicos de alguns bons resultados ${ }^{(10)}$

A citação(1) reflete bem a importância do tema analisado "Os tendões flexores fazem parte de um conjunto anátomo-fisiológico muito complexo da mão. São os principais elementos atuantes nos movimentos de preensão; preensão forte e vigorosa do operário que empunha a sua marreta, preensão delicada e sutil do desenhista que traça as linhas corretas de um perfil de um rosto ou de um hábil cirurgião que maneja o seu bisturi em movimentos rápidos e precisos. Se para o operário a invalidez de uma de suas mãos significa a perda de sua capacidade para o trabalho, para os outros representa toda uma gama de dificuldades a começar pelo seu relacionamento do dia a dia."

Apesar de haver quase um consenso no que se refere à forma de reconstrução das lesões crônicas dos tendões flexores, observamos uma diversidade muito grande em relação aos resultados obtidos, muitas vezes, pouco animadores, o que nos motivou a realização deste trabalho relatando nossa experiência. Baseado em nossos resultados propomos uma discussão sobre os eventuais fatores que contribuem para obtenção de um resultado mais satisfatório.

\section{CASUÍSTICA}

A casuística consta de trinta e seis dedos em vinte e quatro pacientes operados no período compreendido de 1994 a 1997 , onde vinte pacientes eram do sexo masculino, e quatro do sexo feminino. A idade variou de 6 a 47 anos com média de 20 anos. O dedo mais acometido foi $02^{\circ}$ quirodáctilo (44\%); e a zona mais lesada, segundo classificação $\operatorname{Verdan}^{(19)}$, foi a do tipo II em 22 casos (88\%).

O intervalo decorrido entre a lesão e o $1^{\circ}$ estágio cirúrgico variou de $1 \frac{1}{2}$ meses a vinte meses com média de 3 meses.

O sumário geral da casuística está apresentado na (tabela 1), onde se notam número de ordem, iniciais dos pacientes, idade, sexo, tipo de lesão ocorrida, localização das lesões com suas respec- in a first moment. In 1971 refined and detailed the technique of tendon reconstruction in two stages as it is presently knowh, with clinical reports and good results ${ }^{(10)}$.

The quotation"(1) reflects the importance of this theme: "The flexor tendons are part of a very important anatomical-physiological aspect of the hand. They are the main elements which act in prehension movements: strong and vigorous prehension of the worker that holds a hammer, delicate and subtle prehension of the designer who traces the lines of a face, or of a surgeon who uses the scalpel in rapid and accurate movements. If for the worker disability of the hands means loss of capacity to work, for others it represents a spectrum of difficulties starting with the daily life relationships."

Although there is a consensus as concerns reconstruction of the flexor tendons chronic lesions, we observe great disparity as concerns the results, often not very encouraging and this led us to report our experiences in this study. Considering our results we propose a discussion about the factors which can contribute to promote more satisfactory results.

\section{CASUISTIC}

Thirty-six fingers of 24 patients (20 males and 4 females) operated on from 1994 to 1997. The ages ranged from 6 to 47 years, mean 20 years. The most compromised finger was the $2^{\text {nd }}$ chirodactylo (44\%) and the most lesioned zone was type /I according to the Verdan classification ${ }^{(19)}$ in 22 cases (88\%).

The time span between the injury and the $1^{\text {st }}$ surgical stage ranged from 1.5 months to 20 months, mean 3 months.

A general summary of the casuistic is presented (Table 1): number of order, initials of patients, age, sex, type of the lesion, localization of the lesions with their respective zones and time span between the injury and the $1^{\text {st }}$ surgical stage.

All the patients were pre-operatively assessed and classified $^{(6)}$ considering extension of the lesion and establishing prognosis. (Table 2).

Tabela 1 - Sumário geral da casuística.

$\boldsymbol{M}=$ Masculino, $\boldsymbol{F}=$ Feminino, $\mathbf{F c c}=$ Ferimento corto contuso,

$\mathbf{Q D D}=$ Quirodáctilo direito, $\mathbf{Q D E}=$ Quirodáctilo esquerdo, $\boldsymbol{m}=$ meses

Table 1 - Casuistic. $\boldsymbol{M}=$ Male, $\boldsymbol{F}=$ Female,

$F \mathbf{c c}=$ Cut-contusion wound, $Q D D=$ Right chirodactylo,

$\mathbf{Q D E}=$ Left chirodactylo, $\boldsymbol{m}=$ months. 
tivas zonas e o intervalo de tempo entre a lesão e $01^{\circ}$ estágio cirúrgico.

Todos os pacientes foram avaliados pré-operatoriamente e classificados segundo a classificação(6) que considera o grau de extensão da lesão e estabelece também o seu prognóstico. (Tabela 2).

\section{MÉTODO}

\section{Técnica operatória $1^{\circ}$ Estágio}

\begin{tabular}{|l|l|l|}
\hline Grau 1 & Bom (mínima aderência, mobilidade articular) & 02 pacientes \\
\hline Grau 2 & Cicatriz profunda, contratura tecidos moles & 03 pacientes \\
\hline Grau 3 & Rigidez articular (contratura articular) & 04 pacientes \\
\hline Grau 4 & Lesão nervosa (lesão do nervo digital) & 07 pacientes \\
\hline Grau 5 & Múltiplos dedos envolvidos & 07 pacientes \\
\hline Grau 6 & Insolúveis & 01 pacientes \\
\hline
\end{tabular}

Tabela 2 - Classificação de Boyes - Número de pacientes.

Table 2 - Boyes Classification - Number of Patients.

\section{METHODS}

\section{Surgical technique First stage}

The $1^{\text {st }}$ stage consists of a technique to implant a silicone rod all through the flexor tendon until the distal phalanx of the fingers. Some surgical complementary and necessary procedures as capsulotomy or reparation of associated lesions as the digital nerve are also carried out in this stage. We approach the lesion through the Bruner ${ }^{(8)}$ Zig-Zag volar incision (Fig. 1).

The positioning of the silicone rod in the injured finger starts with the insertion of the deep flexor in the distal phalanx until the distal third of the forearm (Fig. 2).

Distally, we always suture the rod to the stump of the remanescent flexor tendon in the distal phalanx, however proximally we let it free. The rod is always passed through the remanescent pulleys (Fig. 3,4).

In this $1^{\text {st }}$ stage, when necessary, we reconstruct pulleys $A 2$ and A4 to avoid the "arch" effect. We use two kinds of tissue, or a portion of the injured finger superficial flexor tendon, or a strip of the extensor retinaculus approximately $0.5 \mathrm{~cm}$ wide at the wrist level. Concerning reconstruction, we use two techniques: type ${ }^{(11)}$, used in 7 cases in which we suture the strip to the fibrous borders of the former shaft; type // ${ }^{2,12)}$, in 11 cases, in which we embrace and surround all bone phalanges under the extensors in the proximal phalanx and over in the middle phalanx (Figs. 5 and 6).

Three days after surgery, we institute passive mobilization of the metacarpus and interphalangeal articulations.

\section{SECOND STAGE}

After a minimum period of 04 (four) months when a pellicle for$m s$ around the silicone creating a new tunnel, we carry out the second phase of the tendoplasty. In this intervention we approach with diminute incisions the sites of the proximal and distal extremities of the already installed silicone rod

Figure 2 - The injured area with intense fibrosis prepared to receive the silicone rod (arrow). tipo I ${ }^{(11)}$ que foi utilizada em 7 casos, onde realizamos a sutura da fita nas bordas fibrosas da antiga bainha e a tipo II ${ }^{(2,12)}$ em 11 casos, onde abraçamos e rodeamos toda a falange óssea por

and substitute this rod by the tendon graft (Figs. 7,8). 
baixo dos extensores na falange proximal e por cima na falange média (Figs. 5 e 6 ).

No pós operatório, iniciamos já no terceiro dia a mobilização passiva das articulações metacarpo e interfalangianas.

\section{Estágio}

Após um período mínimo de 04 (quatro) meses, durante o qual forma-se uma película ao redor do silicone, criando-se um neotúnel, efetuamos a segunda fase da tenoplastia. Nessa intervenção, abordamos com mínimas incisões, as localizações das extremidades proximal e distal do espaçador de silicone já instalado, e substituímos este espaçador pelo enxerto de tendão. (Figs. 7,8).

As fontes de enxerto utilizadas foram: palmar longo ipsilateral, palmar longo contralateral, plantar delgado e extensor curto dos dedos do pé. (Figs. 9,10).

A passagem do enxerto foi feita sempre de distal para proximal, fazendo com que este habite o neo-túnel formado. (Fig. 11).

Distalmente suturamos o enxerto no coto do tendão flexor profundo remanescente que está inserido na falange distal. Para reforço desta sutura, realizamos a técnica do "Pull Out" (14). A sutura proximal do enxerto foi feita no próprio tendão flexor profundo, ou superficial do dedo acometido. Em alguns casos de lesão, utilizamos como força motora, o tendão superficial do dedo vizinho sendo geralmente o do $4^{\circ}$ dedo. Todas as suturas foram realizadas pela técnica Pulvertaft ${ }^{(15)}$. A tensão desta sutura manteve o dedo em um grau de flexão maior que os outros dedos na posição de repouso, quando a sutura era feita no próprio tendão lesado. (Fig.12).

No pós operatório mantivemos o punho em extensão neutra, articulações metacarpofalangianas em $80^{\circ}$ e interfalangianas em $0^{\circ}$. Iniciamos a mobilidade passiva no quinto dia pós operatório e ativa sem resistência no 18 dia. Os pacientes utilizaram órteses por um período total de seis semanas.

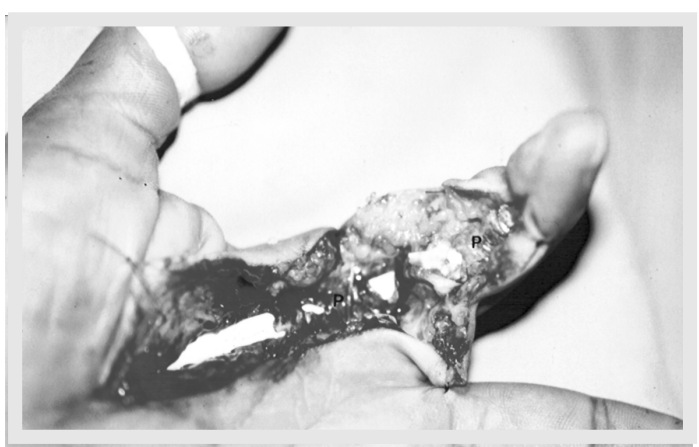

Figura 3 - Observamos o espaçador sob as polias $(P)$ remanescentes.

Figure 3 - Rod under the remanescent pulleys $(P)$.

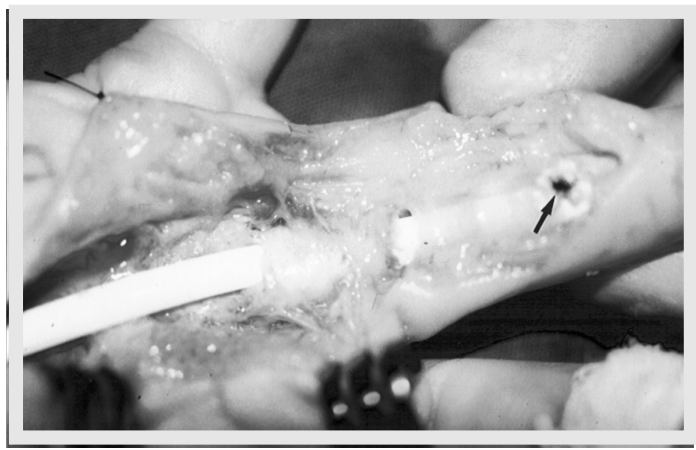

Figura 4 - Identificamos a sutura do espaçador com o coto do tendão flexor profundo (seta).

Figure 4 - Rod suture identified with the stump of the deep flexor tendon (arrow).

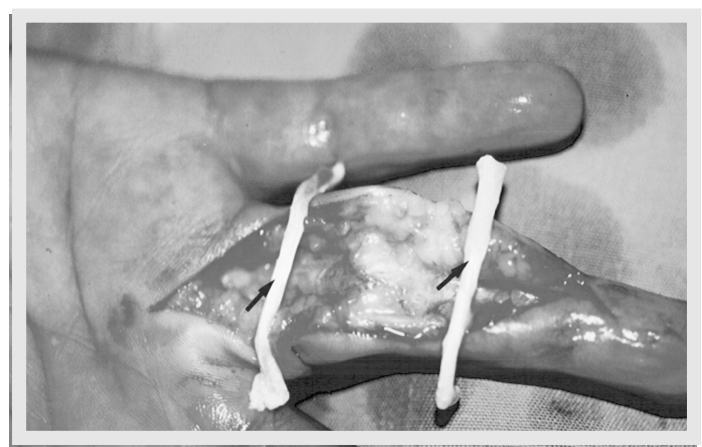

Figura 5 - Observamos as fitas do tendão flexor superficial (seta) nos locais onde serão reconstruídas as polias A2 e A4.

Figure 5 - Strips of the superficial flexor tendon (arrow) in the sites where pulleys A2 and A4 will be reconstructed.
The grafts came from: ipsilateral long palmar, contralateral long palmar, thin plantar and short extensor of the toes (Figs. 9,10).

The graft trajectory was always from distal to proximal, inside the new tunnel (Fig. 11)

Distally, we suture the graft to the stump of the remanescent deep flexor tendon inserted in the distal phalanx. To reinforce this suture, we carry out the "Pull Out" technique(14). The suture proximal to the graft was carried out in the deep flexor tendon, superficially to the injured finger. In some lesions, we use as motor force the superficial tendon of the adjacent finger, generally the $4^{\text {th }}$ finger. All the sutures are carried out using the Pulvertaft(15) technique. Tension of this suture maintains the finger in a flexion grade higher than the other fingers in the rest position, where the suture was made in the lesioned tendon itself. (Fig. 12).

During the post-surgical period the wrist is maintained in neutral extension, the metacarpophalangeal articulations in $80^{\circ}$ and the interphalangeal in $0^{\circ}$. Passive mobility started in the fifth day after surgery and active mobility without resistance in the $18^{\circ}$ day. The patients used orthesis during six weeks.

A general summary of the method is (Table 3), with number of order, initials of the patients, type of the reconstructed pulley, type of reconstruction of the pulley, origin of the grafts, and type of tendon used as motor in the graft proximal suture.

\section{RESULTS}

In the post-surgical evaluation WHITE's ${ }^{(21)}$ method was used, based in the following parameters: loss of extension, total sum of flexion of the interphalangeal and metacarpophalangeal articulations and of the Pulp-Palm distance, as (Table 4 and figures 13,14 and 15).

The results are presented (Table 5), according to the evaIuation criteria proposed by WHITE. 
O sumário geral do método está apresentado na (Tabela 3), onde se notam número de ordem, iniciais do paciente, tipo de polia reconstruída, tipo de reconstrução de polia, as fontes de enxerto utilizadas e o tipo de tendão utilizado como motor na sutura proximal ao enxerto.

\section{RESULTADO}

$\mathrm{Na}$ avaliação pós operatória usou-se a método de WHITE ${ }^{(21)}$, o qual baseia-se nos seguintes parâmetros: perda de extensão, somatória da flexão das articulações interfalangianas e metacarpofalangianas e de distância Polpa-Palma, conforme se vê (Tabela 4 e nas figuras: 13,14 e 15).

Os nossos resultados estão na (tabela 5), que segue os critérios de avaliação propostos por WHITE.

Analisando-se os resultados vemos que $5,5 \%$ foram considerados excelentes (2 dedos), $61,1 \%$ bons (22 dedos), 16,6\% com resultados regulares (6 dedos) e 16,7\% com maus resultados (6 dedos).

\section{COMPLICAÇÕES}

Dez pacientes tiveram as seguintes complicações em 17 dedos:

Aderência ao nível da sutura proximal em 3 dedos (8,3\%) Pacientes números: 01 2QDE, 03 - 4 QDE, 06 - 5 QDE e na distal em 6 dedos $(16,6 \%)$ 6 - 4- QDE, 7- 2QDD, 10 - 4응 QDD, 15 - 3QDD, 13 - 2 QDE, $21-2 \circ Q D D$.

Infecção em 2 dedos (5,5\%) Pacientes números: 21- 2 QDD, 1- 4ㅇQㄹ, migração do espaçador de silicone em 1 dedo (2,7\%) Paciente número 17 - 4ํㅡㄴ QDD.

Afrouxamento do tendão em 4 dedos $(11,1 \%)$ pacientes números 10 - 3 QDD, 18 - 3 QDD, 2 - 3 QDE, 2 - 4ำ QDE. e arco de corda em 1 dedo (2,7\%) Paciente número: 19 - 4 QDD. Não se constatou em nenhum caso ruptura do

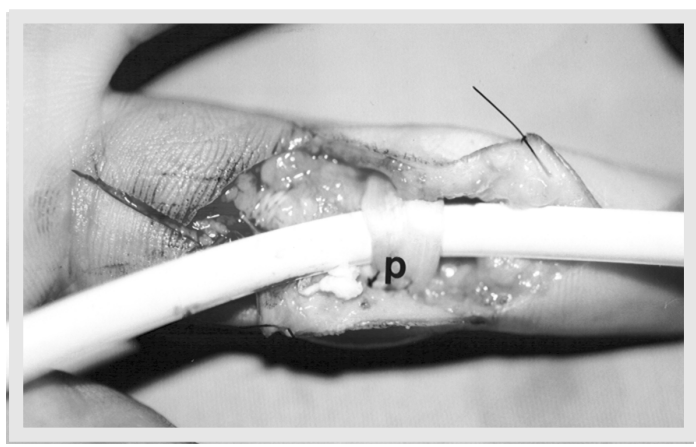

Figura 6 - Identificamos a polia $(P)$ já reconstruída abraçando a falange.

Figure 6 - Pulley $(P)$ already reconstructed embracing the phalanx.

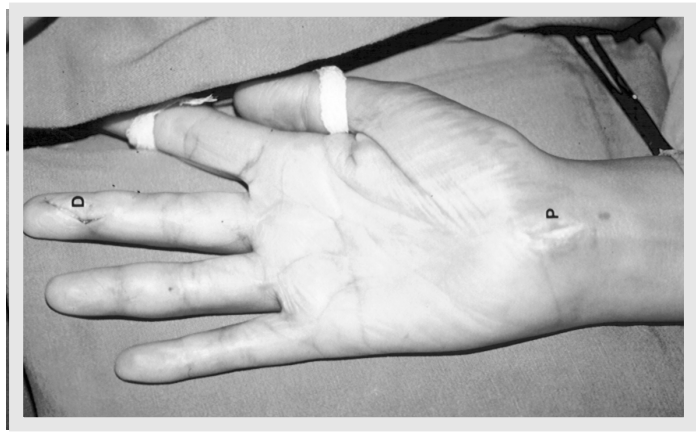

Figura 7 - Identificamos as mínimas incisões do $2^{\circ}$ estágio, tanto distal (D), como proximalmente $(P)$.

Figure 7 - Diminute incisions of the $2^{\text {nd }}$ stage, identified distally $(D)$ and proximally $(P)$.

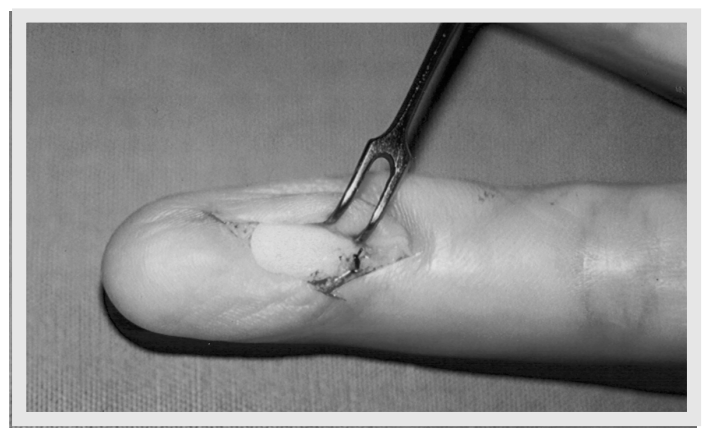

Figura 8 - Detalhe da incisão ao nível da falange distal onde identificamos o espaçador que será substituído.

Figure 8 - Incision at the distal phalanx level showing the rod which will be substituted.
Analyzing the results $5.5 \%$ were considered excellent (2 fingers), 61.1\% good (22 fingers), $16.6 \%$ regular (6 fingers), and $16.7 \%$ bad (6 fingers)

\section{COMPLICATIONS}

Ten patients had the following complications in 17 fingers:

Adherence at the proximal suture in 3 fingers (8.3\%). Patients numbers: $01-2^{\text {nd }} Q D E-03-4^{\text {th }}$ QDE, $06-5^{\text {th }} Q D E$ and distal in 6 fingers (16.6\%) 6 $-4^{\text {th }} Q D E, 7-2^{\text {nd }}$ $Q D D, 10-4^{\text {th }} Q D D, 15-3^{\text {rd }} Q D D$, $13-2^{\text {nd }} Q D E, 21-2^{\text {nd }} Q D D$.

Infection in 2 fingers (5.5\%). Patients numbers: $21-2^{\text {nd }} Q D D, 1-4^{\text {th }}$ $Q D E$, migration of the silicone rod in 1 finger (2.7\%). Patient number 17 $4^{\text {th }} Q D D$.

Tendon loosening in 4 fingers (11.1\%). Patients numbers 10 $3^{\text {rd }} Q D D, 18$ - $3^{\text {rd }} Q D D, 2$ - $3^{\text {rd }}$ $Q D E, 2-4^{\text {th }} Q D E$ and "arch" in 1 finger (2.7\%), patient number 19 - $4^{\text {th }}$ QDD. No cases of tendon graft rupture or sinovitis were observed.

In the cases of adherence, tendolysis was carried out in a second occasion in all the patients. The cases of infection were treated with antibiotics and reoperated on in a second occasion. In the patients with rod migration, repositioning was carried out; afterwards, the normal surgical technique was used in the cases with visible tendon loosening and reconstruction of the pulley was effected in the "arch" case using the type /I technique.

\section{DISCUSSION}

When a flexor tendon lesion is found at the hand level, it is of the utmost importance to classify it in acute or chronic. If the acute lesions when treated have a better prognosis, the same does not happen with the chronic lesions which demand a more complex reconstruction, with a higher margin of unsatisfactory results. Among the chronic lesions, the worst as concerns prognosis are those with grade above 3 , according to the Boyes ${ }^{(6)}$ 
enxerto de tendão ou sinovite.

Para as aderências tendinosas foram realizados tenólises em segundo tempo em todos os pacientes. Os casos de infecção foram tratados com antibioticoterapia e reoperados em segundo tempo. No paciente em que houve a migração do espaçador, este foi reposicionado e seguida; posteriormente a técnica normal de cirurgia, para os casos visíveis de afrouxamento do tendão foi feito retesamento e para o caso do "arco de corda" foi feito a reconstrução da polia pela técnica do tipo II.

\section{DISCUSSÃO}

Quando deparamos com uma lesão dos tendões flexores a nível da mão, é de suma importância sua divisão em: aguda ou crônica. Se por um lado as lesões agudas, quando tratadas, tem um prognóstico melhor, não podemos dizer o mesmo das lesões crônicas em que se faz necessário, uma reconstrução mais complexa e portanto sujeita a uma margem maior de resultados insatisfatórios. Pela classificação de Boyes ${ }^{(6)}$, dentre as crônicas, as piores quanto ao prognóstico são as de grau maior do que 3. A maioria dos casos por nós tratados são lesões crônicas assim classificadas, portanto, os piores casos.

Em relação ao primeiro estágio cirúrgico consideramos importante uma ampla exposição da região volar do dedo acometido para que possamos avaliar as condições das polias remanescentes, e quando de sua inviabilidade, realizarmos a reconstrução de pelo menos as A 2 e A 4. Pois sem estas polias, na flexão do dedo ocorre o "arco de corda" já mencionado e observado no paciente $n^{\circ} 19$ (Figs. 16 a 19). Para reconstrução de uma polia recorremos a uma fita transversa do retináculo extensor do carpo, quando havia necessidade de mais de uma polia recorríamos ao flexor superficial do próprio dedo acometido. Observamos que o tipo

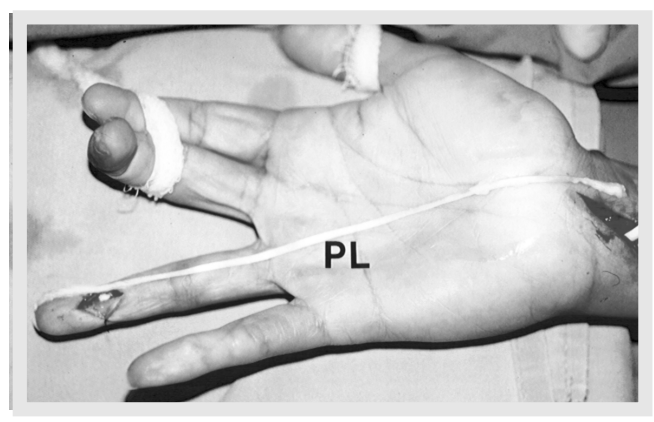

Figura 9 - Enxerto de tendão palmar longo ( $P L)$. Figure 9 - Long palmar tendon graft (PL).

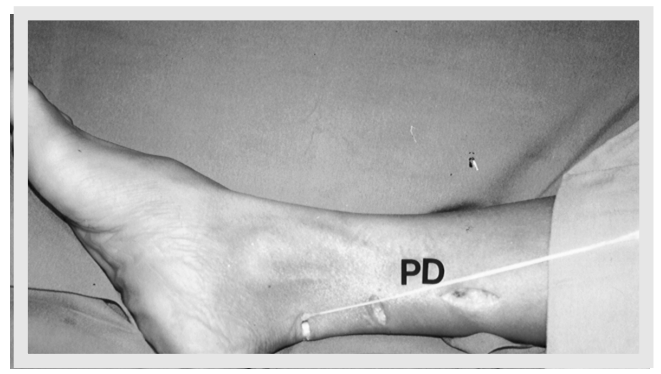

Figura 10 - Plantar delgado (PD). Figure 10 - Thin plantar $(P D)$.

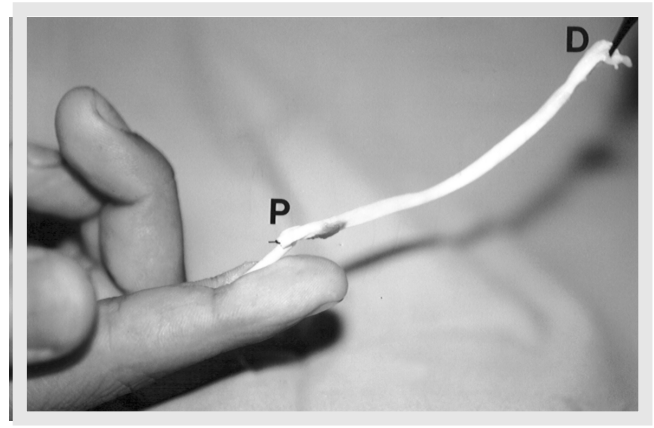

Figura 11 - Observamos o enxerto de tendão (seta) suturado ao espaçador que será tracionado de distal para proximal.

Figure 11 - Tendon graft (arrow) sutured to the rod that will undergo traction from distal to proximal.

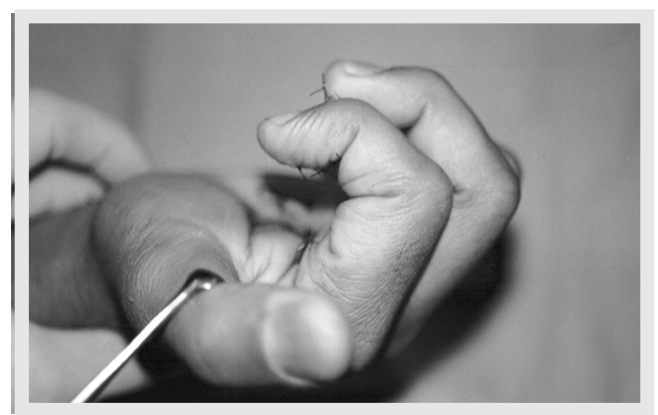

Figura 12 - Regulagem do grau de flexão desejado. Observamos o $2^{\circ}$ dedo com tensão maior.

Figure 12 - Adjustment of the flexion grade. The $2^{\text {nd }}$ finger shows more tension. classification. Most of the cases we treated are chronic lesions classified as grade 3 by this classification, thus, the worst cases.

As concerns the first surgical stage, we consider important a wide exposition of the injured finger volar region to assess the conditions of the remanescent pulleys; when this is not feasible we carry out the reconstruction of at least A2 and A4. In the absence of these pulleys, when the finger is flexioned, the already mentioned "arch" is observed as in patient number 19 (Figs. 16 to 19). For the reconstruction of a pulley we use a transverse strip of the extensor retinaculus of the carpus; when another pulley is necessary we use the superficial flexor of the injured finger. We observed that in the reconstructions where suture was made only at the borders of the remanescent shaft (type I), original technique described(11), good results were not a certainty. Thus, we made the reconstruction of the pulley with the ring form ${ }^{(2,12)}$ around the proximal and middle phalanges circumference. Thus, we obtained a more resistant new pulley avoiding the "arch" effect. The patients operated on according to type /I presented better results, as patients number $5-5^{\text {th }} Q D E, 9-3^{\text {rd }} Q D D, 12-$ $2^{\text {nd }} Q D E, 15-3^{\text {rd }} Q D D, 17-5^{\text {th }}$ $Q D D, 23-3^{\text {rd }} Q D D, 23-4^{\text {th }} Q D D$, $23-5^{\text {th }} Q D D, 24-2^{\text {nd }} Q D D, 11-$ $4^{\text {th }} \mathrm{QDD}$.

This technique is not used in thumb lesions since we believe that in these cases the transposition of the flexor superficial to the $4^{\text {th }}$ finger presents better results.

Only after a minimum period of 4 months the second stage was carried out, a basic pre-requisite being the total passive articular amplitude of the injured finger. In spite of individual differences, the orientations concerning the postsurgical rehabilitation process were uniformly made.

In relation to the second stage of reconstruction, we considered 
de reconstrução onde a sutura era feita apenas suturando-se nas bordas da bainha remanescente (tipo I) técnica original, descrita ${ }^{(11)}$ não garantia os bons resultados. Portanto passamos a proceder a reconstrução da polia em forma de anel ${ }^{(2,12)}$, ao redor de toda a circunferência da falange proximal e média. Desta forma obtínhamos uma nova polia com maior resistência evitando-se assim o efeito em arco de corda. Os pacientes operados pelo tipo II apresentaram meIhores resultados, como nos pacientes números: 5 - 5 QDE, 9 - 3QDD, 12 - 2QDE, 15 - 3 QDD, 17 - 5 QDD, 23 - 3 QDD, 23 - 4QDD, 23 - 5 QDD, 24 - 2QDD, 11 - 4 QDD

Não usamos esta técnica em nenhuma lesão do polegar, pois acreditamos que nestes casos, a transposição do flexor superficial do 4을 dedo tenha melhores resultados.

Somente após um período mínimo de 4 meses é que era realizado o $2^{\circ}$ estágio, tendo como prérequisito básico a amplitude articular passiva total do dedo acometido. Apesar das diferenças individuais, as orientações quanto ao processo de reabilitação pós-operatória eram feitas de maneira uniforme.

Em relação ao segundo estágio da reconstrução, consideramos alguns pontos importantes que levam a um resultado final mais satisfatório. São estes: o tipo de enxerto, a forma de fixação distal do enxerto, a unidade motora a ser utilizada, a tensão da sutura que devemos manter ao tendão reconstruído e fisioterapia pósoperatória

Como fonte doadora de enxerto nossa prioridade recaiu

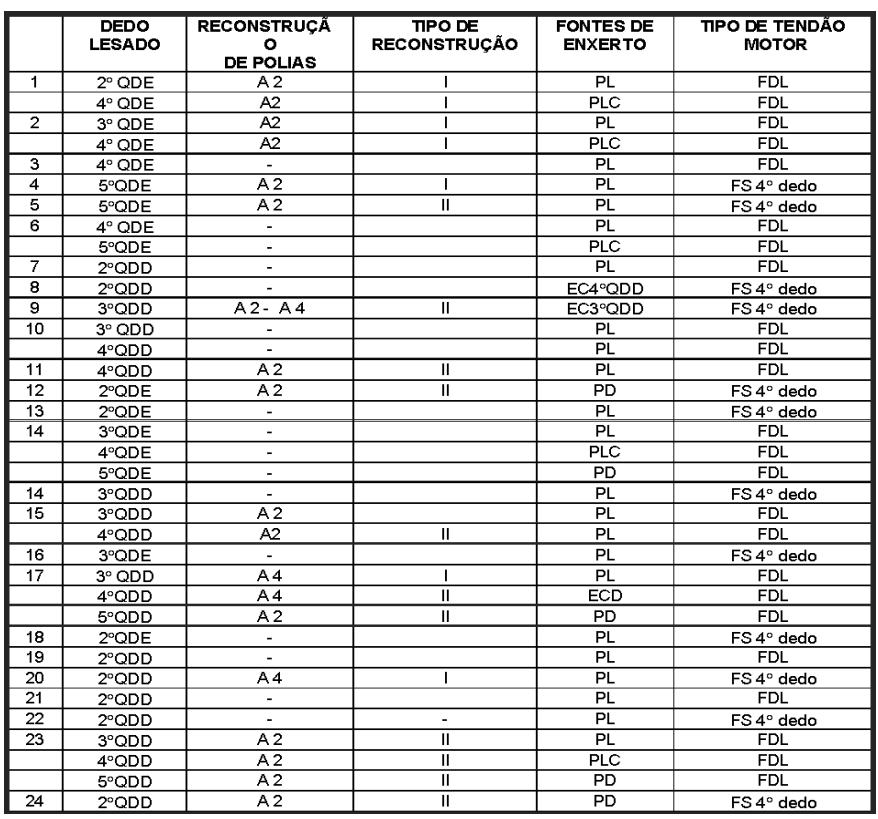

Tabela 3 - Sumário geral do método

PLC. $=$ Palmar longo contralateral, PL. = Palmar Longo,

PD. = Plantar Delgado, ECD = Extensor curto dedos,

$\boldsymbol{F D L}=$ Flexor do dedo lesado, $\boldsymbol{F S} 4^{\circ}$ dedo $=$ Flexor

superficial do $4^{\circ}$ dedo, $\boldsymbol{A}_{2}=$ Polia $A_{2}, \boldsymbol{A}_{4}=$ Polia $A_{4}, \boldsymbol{I}=$ Reconstrução

Tipo I (vide texto), II = Reconstrução Tipo II (vide texto).

Table 3 - General Summary of the Method.

PLC. $=$ Contralateral Long Palmar, PL. $=$ Long Palmar, $P$ D. $=$ Thin

Plantar, $\mathbf{E C D}=$ Finger Short Extensor, $\boldsymbol{F D L}=$ Lesioned Finger Flexor, FS $4^{\circ}$ dedo $=4$ th Finger Superficial Flexor,

$\boldsymbol{A}_{2}=$ Polia $A_{2}, \boldsymbol{A}_{4}=$ Polia $A_{4}, I=$ Reconstrução Tipo I (vide texto), II = Reconstrução Tipo II (vide texto).

\begin{tabular}{|c|c|c|c|}
\hline & PERDA DA EXTENSÁO & SOMATÓRIA DA FLEXÃO & DISTÃNCIA POLPA -PALMA \\
\hline Excelente & Ausente & $200^{\circ}$ & $1,3 \mathrm{~cm}$ \\
\hline Bom & Até $30^{\circ}$ & $180^{\circ}$ & Até $2,5 \mathrm{~cm}$ \\
\hline Regular & Até $40^{\circ}$ & $150^{\circ}$ & Até $3,8 \mathrm{~cm}$ \\
\hline Mau & Além de $40^{\circ}$ & $<150^{\circ}$ & $>3,8$ \\
\hline
\end{tabular}

Tabela 4 - Critérios de Avaliação de White.

Table 4 - White's Evaluation Criteria.

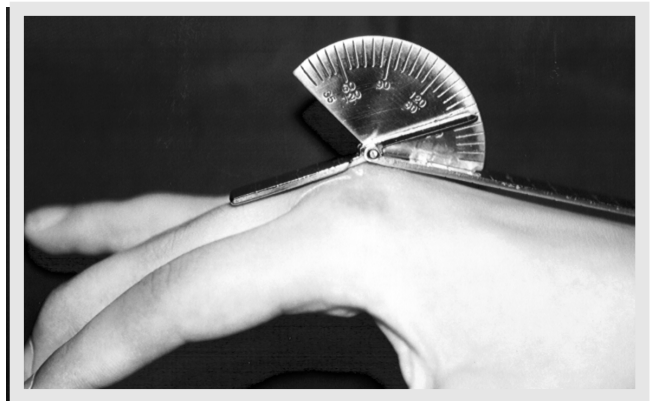

Figura 13 - Exame demonstrativo da perda da extensão pela técnica de White.

Figure 13 - Demonstrative exam of the extension loss, according to White. some important aspects leading to a more satisfactory final result. They are: type of graft, form of the distal fixation of the graft, motor unit to be used, suture tension to be maintained in the reconstructed tendon, and physiotherapy post-surgery.

As concerns the graft sources our priorities were the long palmar tendon, thin plantar and short extensor of the toes, in that order. The long palmar tendon offers more advantages and it is the most used. When more than one graft is necessary (case of two or more lesioned fingers), we obviously obtained grafts in other sites. Passage of the graft through the already prepared tunne/ was the least traumatic possible with small incisions both at the wrist level and in the base of the finger distal phalanx.

As concerns the distal fixation of the graft we considered more secure to complement the suture with a "pull out" (18).

We must also consider the importance of the skin closure in the region of the distal suture before starting the proximal suture, since after the latter we will have difficulty to approach the finger volar region due to its flexed position. At the level of the proximal suture, we have no doubt that its realization in zone 5 is the factor with best prognosis than when it is effected in other level, since the adherence risk is smaller ${ }^{(5)}$.

After the tendon is cut retraction occurs not only of the tendinous segment but also and mainly of the muscular aspect. If at the moment of utilization we try to elongate it, it will not be possible to obtain the normal length; this will occur during the rehabilitation process. We consider this aspect the main cause of reconstruc- 
sobre o tendão do palmar longo, plantar delgado e o extensor curto dos dedos do pé, nesta ordem. Quando presente o tendão palmar longo oferece mais vantagens, sendo o mais utilizado. Quando foi necessário mais de um enxerto (caso de dois ou mais dedos lesados) obviamente realizamos a retirada de enxerto de outros locais. A passagem do enxerto pelo túnel já preparado foi a menos traumática possível com a realização de incisões pequenas tanto a nível do punho como na base da falange distal do dedo.

Em relação à fixação distal do enxerto achamos mais seguro complementar a sutura com a realização de um "pull-out"(18). Devemos lembrar também da importância do fechamento da pele na região da sutura distal antes do inicio da sutura proximal, pois após esta teremos dificuldade em abordar a região volar do dedo devido à sua posição de flexão. A nível da sutura proximal, não temos dúvida em afirmar que a sua realização na zona 5 é fator de melhor prognóstico do que as realizadas em outro nível, já que o risco de aderência é menor ${ }^{(5)}$.

Uma vez secionado o tendão temos uma retração não só do segmento tendíneo como principalmente da porção muscular. Mesmo que no momento de sua utilização procuremos fazer seu alongamento, acreditamos não ser possível obter seu comprimento normal, o que irá ocorrer contudo ao longo do processo de reabilitação. A nosso ver esta é a principal causa da frouxidão que acaba se sucedendo no tendão reconstruído. Com relação a escolha da unida-

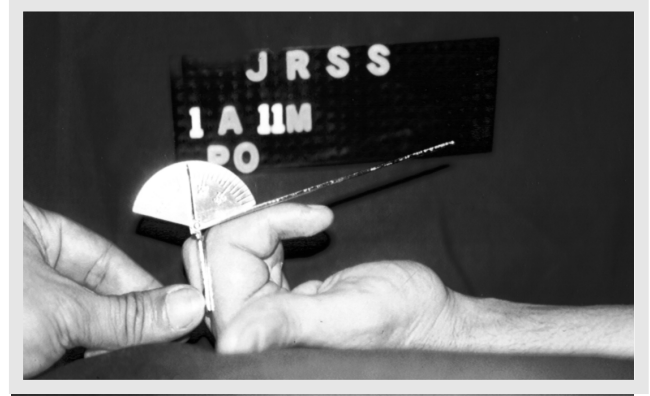

Figura 14 - Exame demonstrativo da somatória da flexão pela técnica de White.

Figure 14 - Demonstrative exam of flexion total sum, according to White.

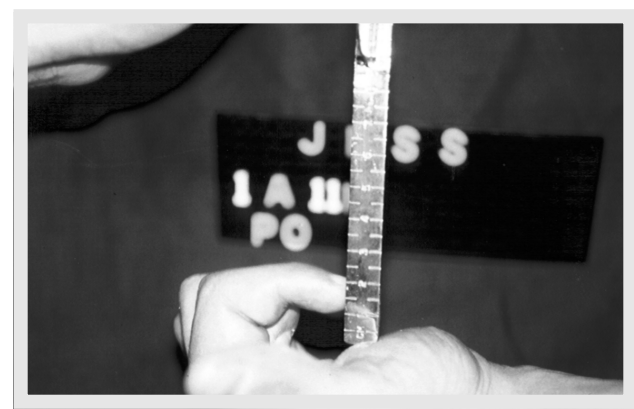

Figura 15 - Exame demonstrativo da distância Polpa Palma pela técnica de White.

Figure 15 - Demonstrative exam of the PulpPalm distance, according to White. ted tendon loosening. As concerns the choice of the motor unit we used the deep or superficial flexor of an adjacent finger. The utilization of the superficial flexor of a normal adjacent finger, in general de fourth finger, provides better results as concerns not losing tension during the rehabilitation process. Thus, we think that in case we use as motor unit the lesioned finger, the tension of the intra-surgery suture will be higher, and this will be observed in the greater flexion of the finger in relation to others in the rest position, contrary to the utilization of an adjacent tendon where we can adjust tension in order that the finger assumes a rest position similar to the anatomical.

The patients with loosening due to post-surgical loss of tension were submitted to another intervention to stretch, and we noticed that after surgery significant improvement was observed in three cases. Patients numbers $2-3^{\text {rd }}$ $Q D E, 2-4^{\text {th }} Q D E, 10-3^{\text {rd }} Q D E$, show the importance of "regulating" tension during suture.

We also emphasize the importance of the physiotherapy postoperatively calling the attention to the position of the proximal interphalangeal articulations which must always be in position of complete extension $\left(0^{\circ}\right)$, since the retraction in flexion of the articulation can compromise the result.

We adopted WHI$T E^{\prime} S^{(21)}$ classification because it presents more complete parameters, making possible a better analysis of the results, though sometimes it is difficult to compare it with other less strict ones found in the literature,.

The flexor tendon reconstruction in chronic lesions a rescue opera- 
de motora utilizamos o flexor profundo ou superficial de outro dedo adjacente. A utilização do flexor superficial de um dedo adjacente normal, em geral o quarto dedo, proporciona maior previsibilidade quanto a não perda de tensão ao longo do processo de reabilitação. Portanto, achamos que no caso de utilizarmos como unidade motora o próprio dedo lesado, a tensão da sutura no intra-operatório deverá ser maior, o que será observado pela maior flexão do dedo em relação aos demais na posição de repouso, ao contrário da utilização do tendão adjacente em que poderemos ajustar a tensão de forma que o dedo assuma uma posição de repouso próxima à anatômica.

Nos pacientes que apresentavam "frouxidão", por perda da tensão pós operatória realizamos nova intervenção para retesamento e notamos que após a cirurgia houve melhora significativa em 3 casos. Paciente números: 2 - 3QDE, 2 - 4ㅇ QDE, 10 - 3은 QDE, mostrando a importância da "regulagem" da tensão na sutura.

Ressaltamos também a importância da fisioterapia pósoperatória onde chamamos à atenção para a posição das articulações interfalangianas proximais que devem sempre, estar em posição de extensão completa $\left(0^{\circ}\right)$, pois a retração em flexo da articulação, acaba comprometendo o resultado.

A razão de adotarmos a classificação de WHITE ${ }^{(21)}$ é que a mesma apresenta parâmetros mais completos, possibilitando assim uma melhor análise dos resultados, embora as vezes se torne difícil compararmos com outras da literatura, menos rigorosas.

A reconstrução de tendões flexores em lesões crônicas é considerada uma verdadeira operação de salvamento ${ }^{(16)}$. Nossos resultados mostraram, quando comparados com a literatura ${ }^{(4,7,9,14 \text { e 15) }}$ uma média maior de bons resultados; talvez porque tenhamos utilizado os detalhes de técnica já mencionados, que teriam influenciado os nossos resultados (diminuição da

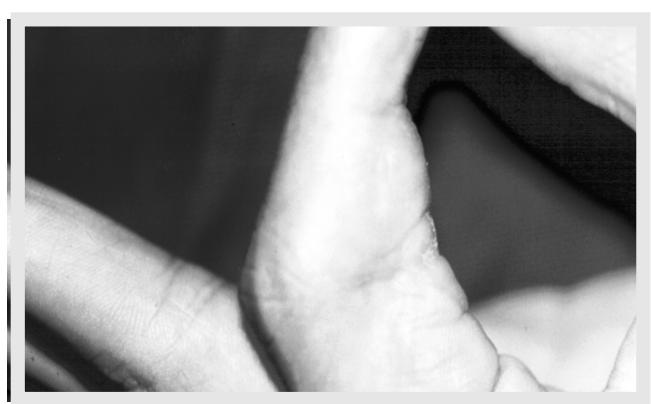

Figura 17 - Formação de "Arco de Corda" após 6 meses de pós operatório.

Figure 17 - Formation of "arch" 6 months after surgery.

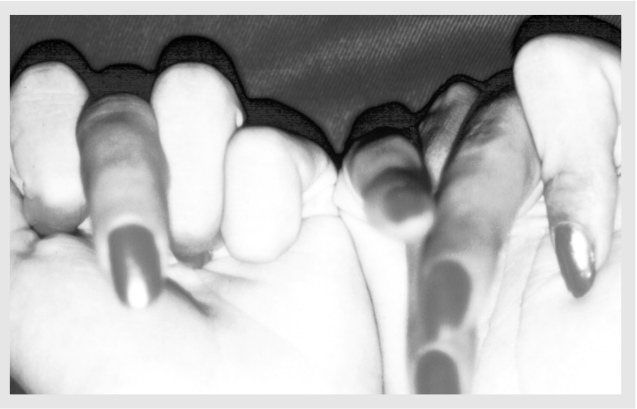

Figura 19 - Lesão crônica bilateral de tendões flexores após FCC.

Figure 19 - Bilateral chronic lesion of flexor tendons after FCC.

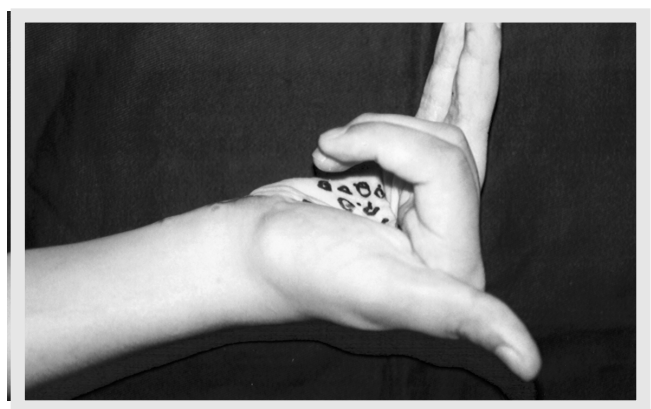

Figura 21 - Resultado final do $3^{\circ}$ dedo após seis meses.

Figure 21 - Final result, $3^{\text {rd }}$ finger, after six months. colocação dos espaçadores (mão esquerda).

Figure 20 - Aspect of the rod placement in the first stage (left hand). tion ${ }^{(16)}$. When compared with the literature ${ }^{(4,7,9,14,15)}$ our results have better means as concerns good results, probably because we use the above mentioned technical details (less incidence of bad results). Patient number 14 illustrates this (Figs. 20 to 24). 


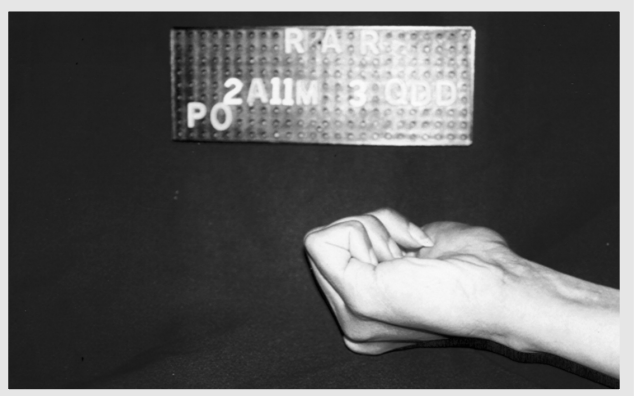

Figura 22 - Resultado final da mão direita ( $3^{\circ}$ dedo) após dois anos e onze meses de pós operatório.

Figure 22 - Final result, right hand ( $3^{\text {rd }}$ finger), two years and eleven months after surgery.

incidência de maus resultados). Como demonstramos no paciente número 14 (Figs. 19 a 23).

\section{CONCLUSÃO}

A reconstrução dos tendões flexores em dois estágios pode melhorar significativamente a função dos dedos lesados que apresentam extensa fibrose ou aderência do mecanismo flexor.

\section{REFERÊNCIAS BIBLIOGRÁFICAS}

1. ABREU, L. B. de. Citação em tese de doutorado sobre tenoplastia em dois estágios nas secções traumáticas dos tendões flexores nos dedos da mão, dentro da bainha fibrosa. Arakiri, T. Comunicação Pessoal, Tese Doutorado à USP: 01, 1972.

2. ARONS, M. S. A-new tendon pulley passes. J. Hand Surg. 10 - A: 758-759, 1985

3. BASSETT, A. L. \& CARROLI, R. E. Formation of tendon sheatt by silicone-rod implants. J. Bone Joint Surg (Am) 45: 884-885, 1963.

4. BECKER, H. Primary repair of flexor tendons in the hand without in immobilisation- preliminary report. Hand. 10: 37-47, 1978.

5.BISHOP, A. T. Flexor mechanism reconstruction and rehabitation. Surgery of the hand and upper extremity, 48: 1133-1161, 1991.

6. BOYES, J. H. Flexor - Tendon grafts in the fingers and thumb. J. Bone Joint Surg., 53 - A : 1332-1342,1971.

7.BRUG, E. \& STEDTFELD, H. W. Experience with a two-stage pedicled flexor tendon graft. Hand 11: 198-205, 1979

8. BRUNNER, J. M. The Zig - zag volar - digital incision for flexor tendon. Surgery. Plast. Reconstr. Surg. 10:571-574, 1967.

9. GONZALEZ, R. Experimental tendon repair with the flexor tunnels. J. Bone. J. T. Surgy Amer Vol 35 A: 941, 1953.

10. HUNTER, J. M. \& SALISBURE, R. E. Flexor tendon reconstruction in severely damaged hands: A two - stage procedure using a silicone - dacron reinforced glicing prosthesis prior to tendon grafting. J. Bone Joint Surg. (Am) 53: 829-858, 1971.

11. KLEINERT, H. E. \& BENNETT, J. B. Distal pulley reconstruction employing the always presents rim of the previous pulley. J. Hand. Surg 3: 297-298, 1978.

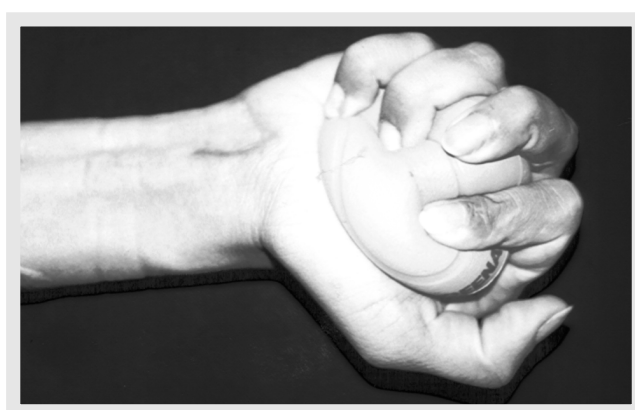

Figura 23 - Paciente apresentando boa força de preensão.

Figure 23 - Patient with good grasping strength.

\section{CONCLUSIONS}

Reconstruction of flexor tendons in two stages can significantly improve the function of lesioned fingers presenting extense fibrosis or adherence of the flexor mechanism.

12. KOCK, S. L. Complicated contractures of the hand, their treatment by freeing fibrosed tendon and replacing destroyed tendons with grafts. Am Surg 98: 546-580,1933.

13. MAYER, L. \& RANSOHOFF, N.S. Reconstruction of the distal tendon sheath contribution to the Physiological method of Repair of damanged finger tendon. J. Bone Joint Surg 18: 607, 1936.

14. PAVENA HOLEVICH, E. Two - stage tenoplasy in injury of the flexor tendons of the hand. J. Bone and Joint Surg. , 51 - A : 21-32, 1969.

15. PUVERTAFT, R. G. The results of tendons grafting for flexor tendon injuries in fingers and thumb after long delay. Bull Hosp. Joint. Dis. , $21: 317-321,1960$

16. SCHIMTZ, P. W. \& STROMBERG, W. B. Two - Stage flexon tendon reconstruction in the hand. Clin Orthop 131: 185-190, 1978.

17. SCHNEIDER, L. H. Staged flexon tendon reconstruction using the method of Hunter: A personal series involving 57, flexor tendon. J. Hand. Surg 3: 287, 1978.

18. TUBIANA, R. Pos-Operative care following flexor tendon grafting. Hand 6: 132-154, 1974.

19. VERDAN, C. Pratical considerations for primary and secondary repair in flexor tendon injuries. Surg. Clin. north. Am., 44 : 951-970, 1964.

20. WENSTEIN, S.; SPRAGUE, B. L. \& FLATT, A. Evaluation of the two - stage flexor tendon reconstruction in severely damaged digits. J. Bone Surg 58 - A: 786-791, 1976.

21. WHITE, R.; MENIMAN, P. Mc \& GORDON, S. Evaluation of results in flexor tendon surgery. Ann Chirurgu $33: 659-662,1979$. 